\title{
Mucosal Schwann Cell Hamartoma in Colorectal Mucosa: A Rare Benign Lesion That Resembles Gastrointestinal Neuroma
}

\author{
Jiheun Han · Yosep Chong · Tae-Jung Kim · Eun Jung Lee · Chang Suk Kang \\ Department of Hospital Pathology, College of Medicine, The Catholic University of Korea, Seoul, Korea
}

The term mucosal Schwann cell hamartoma (MSCH) was first proposed by Gibson and Hornick in $2009^{1}$ to describe a group of neuronal polyps purely composed of S-100-positive Schwann cells, in an attempt to distinguish from true "neuromas" and "neurofibromas." To our knowledge, only 10 cases have been reported in the literature since it was first described (Table 1). $\mathrm{MSCH}$ is currently thought to have no association with any inherited disorder. Herein, we describe a case of $\mathrm{MSCH}$ and discuss the morphologic and immunohistochemical features with a differential diagnosis in the gastrointestinal (GI) tract.

\section{CASE REPORT}

A 2-mm-sized rectal polyp was found in a follow-up colonoscopy of a 49-year-old male who has no significant family history of other neuronal lesions or inherited syndromes but had a tubular adenoma resected 2 years prior (Fig. 1A). On microscopic examination, the rectal polyp showed a poorly circumscribed proliferation of spindle cells in the lamina propria, separating the crypt architecture (Fig. 1B). The cells were uniformly elongated, with tapered nuclei and abundant eosinophilic cytoplasm with indistinct cell borders. Nuclear atypia, pleomorphism, or mitosis was not observed (Fig. 1C). On immunohistochemical staining, the cells displayed a strong and diffuse positivity for S-100 in both the nucleus and cytoplasm (Ventana, Roche, Tucson, AZ, USA) (Fig. 1D). In comparison, the cells did not have im- munoreactivity for c-Kit, CD34, glial fibrillary acidic protein, epithelial membrane antigen (EMA), smooth muscle actin, or neurofilament protein (NFP). Because the spindle cells did not form a discrete mass but rather an interspersed proliferation between normal structures, the lesion was diagnosed as MSCH.

\section{DISCUSSION}

A diagnosis of $\mathrm{MSCH}$ should be made after exclusion of other lesions that resemble spindle cell proliferation and other neuronal tumors. Gastrointestinal stromal tumors, which are the most common spindle cell tumor in the GI tract, can be easily excluded by the characteristic immunoreactivity of c-Kit.

Colorectal neurofibromas are another important differential diagnosis of MSCH because they are also composed of Schwann cells, fibroblasts, perineural cells, and NFP-positive axons and usually form a vague tumor without discrete demarcation. However, they are often associated with neurofibromatosis type 1 (NF1), which is usually accompanied by multiple cutaneous neurofibromas. Colorectal lesion as a primary clinical presentation without skin manifestation is also exceedingly rare. ${ }^{1}$

Mucosal neuromas appear as an ill-defined mass and are composed of hyperplastic nerve fibers arranged in an irregularly ramifying manner. ${ }^{1}$ In contrast to our case, mucosal neuromas have perineurial capsules, which are often EMA-positive. They are almost always multiple and a part of the multiple endocrine neoplasia syndrome type IIb (MEN2B), of which the most important component is a medullary thyroid carcinoma.

GI ganglioneuromas are most common in colorectal neuronal lesions and reveal hypercellular stroma composed of mainly S-100-positive Schwann cells. They differ from MSCH in that they are mixed with variable numbers of neuron-specific enolase- 
positive ganglion cells. ${ }^{1,2}$ Solitary polypoid ganglioneuromas are not associated with systemic manifestations; ${ }^{3}$ however, ganglioneuromatous polyposis and diffuse ganglioneuromatosis are associated with Cowden syndrome, Juvenile polyposis syndrome, MEN2B (particularly with diffuse ganglioneuromatosis), and $\mathrm{NF} 1{ }^{4}$

Table 1. Features of Schwann cell hamartoma repoerted in colorectum

\begin{tabular}{|c|c|c|c|c|c|c|c|}
\hline Reference & Year & $\begin{array}{l}\text { No. of } \\
\text { cases }\end{array}$ & Location & Age (yr) & Sex & Symptom & Endoscopic finding \\
\hline Gibson and Hornick ${ }^{1}$ & 2009 & 26 & $\begin{array}{l}\text { Predominantly in } \\
\text { rectosigmoid colon }\end{array}$ & $\begin{array}{c}\text { Mean } 62 \\
(46-88)\end{array}$ & $\begin{array}{l}\mathrm{M}: F= \\
10: 16\end{array}$ & $\begin{array}{l}\text { Asymptomatic } \\
\text { (most common), diarrhea, } \\
\text { lower Gl bleeding }\end{array}$ & $\begin{array}{l}\text { Sessile polyp, 1-6 mm } \\
\text { (mean, } 2.5 \mathrm{~mm} \text { ) }\end{array}$ \\
\hline Pasquini et al. ${ }^{6}$ & 2009 & 1 & Rectosigmoid colon & 60 & $\mathrm{~F}$ & Occult blood in the stool & Sessile polyp, $5 \mathrm{~mm}$ \\
\hline Rocco et al. ${ }^{5}$ & 2011 & 1 & Sigmoid colon & 67 & F & Asymptomatic & Sessile polyp, 3 mm \\
\hline Sagami et al. ${ }^{7}$ & 2012 & 1 & Sigmoid colon & 40 & M & Occult blood in the stool & $\begin{array}{l}\text { Many small whitish nodules } \\
\text { in mucosa }\end{array}$ \\
\hline Bae et al. ${ }^{3}$ & 2013 & 1 & Descending colon & 41 & $\mathrm{~F}$ & Asymptomatic & Polyp, 8 mm \\
\hline Neis et al. ${ }^{4}$ & 2013 & 1 & Sigmoid colon & 59 & M & Underlying ulcerative colitis & Polyp, 3 mm \\
\hline $\begin{array}{l}\text { Ferro de Beca } \\
\text { et al. }{ }^{8}\end{array}$ & 2014 & 1 & Sigmoid colon & 72 & M & Asymptomatic & Polyp, 5 mm \\
\hline Klair et al. ${ }^{2}$ & 2014 & 1 & Rectum & 78 & F & $\begin{array}{l}\text { Abdominal pain and } \\
\text { intermittent tenesmus }\end{array}$ & $\begin{array}{l}\text { Polyp, } 7 \mathrm{~mm} \text { along with rectal } \\
\text { erythema and inflammation }\end{array}$ \\
\hline Kanar et al. ${ }^{9}$ & 2015 & 1 & Sigmoid colon & 67 & M & Asymptomatic & Polyp, 6 mm \\
\hline Bae et $a l . .^{10}$ & 2015 & 1 & Rectum & 20 & M & $\begin{array}{l}\text { Abdominal discomfort and } \\
\text { loose stools }\end{array}$ & $\begin{array}{l}\text { Polyp, } 4 \mathrm{~mm} \text { and scattered } \\
\text { tiny polyp-like mucosal } \\
\text { elevation }\end{array}$ \\
\hline Present case & 2015 & 1 & Rectum & 49 & M & Asymptomatic & $\begin{array}{l}\text { Tiny polyp-like mucosal } \\
\text { elevation, } 2 \mathrm{~mm}\end{array}$ \\
\hline
\end{tabular}

M, male; F, female; Gl, gastrointestinal.
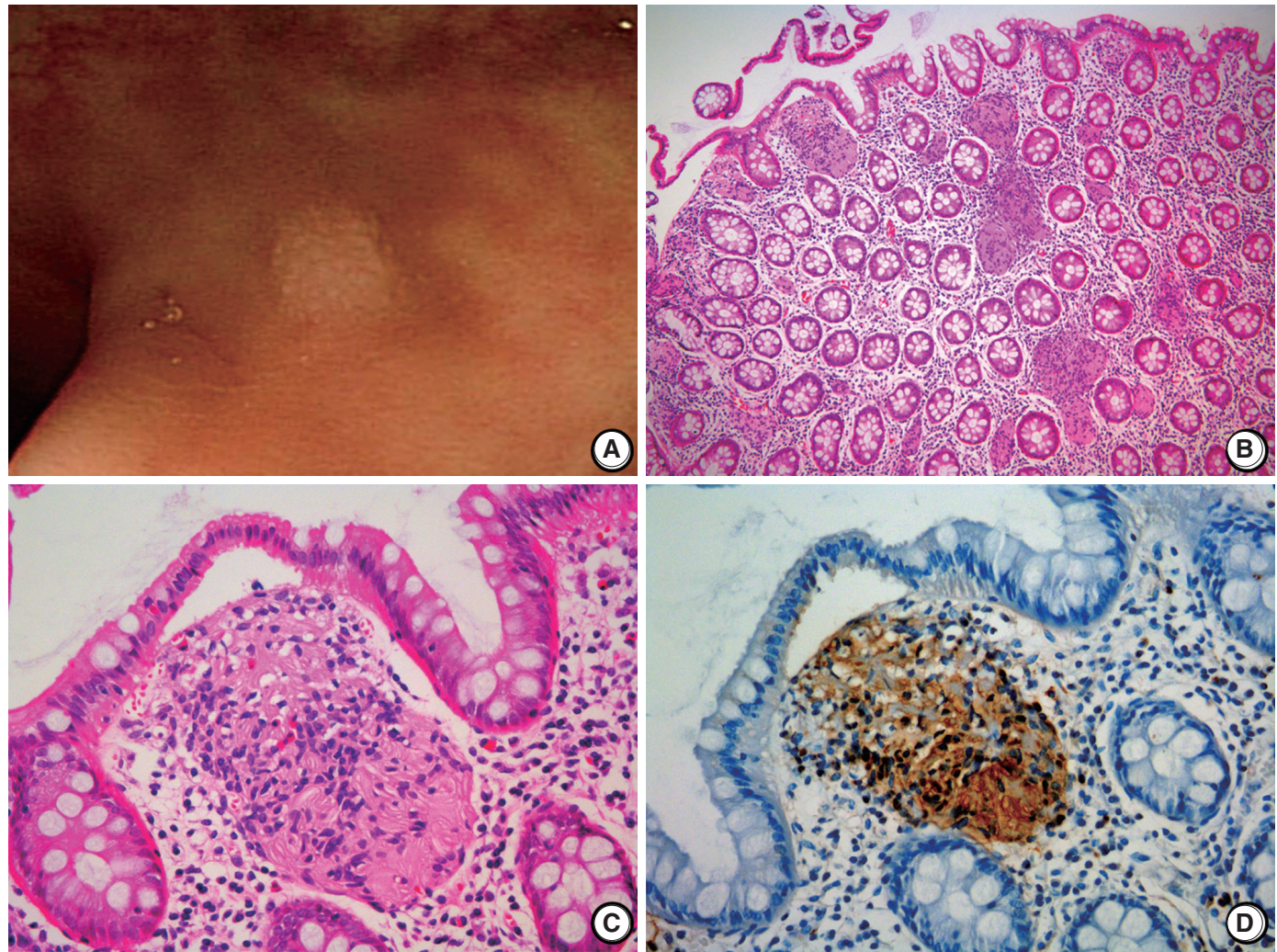

Fig. 1. Schwann cell hamartoma of rectal mucosa. (A) Colonoscopy shows a 2-mm sized tiny polyp-like mucosal elevation without erosion or ulceration. (B, C) Hematoxylin and eosin shows scattered proliferation of bland spindle cells in the lamina propria. (D) Immunohistochemical staining for S-100 displays a positivity of both nucleus and cytoplasm. 
GI schwannomas are composed of bland spindle cells arranged in vague fascicles. Unlike their counterparts from the central nervous system and peripheral soft tissue, the nuclear palisading, so-called Verocay bodies, are absent, which can be similar to MSCH. However, they have characteristic peripheral lymphoid cuffs and form more demarcated tumors than do $\mathrm{MSCH}^{4}$,

Mucosal perineuromas are usually solitary lesions and are characterized by a whorled growth pattern of bland spindle cells that expand the lamina propria, ${ }^{5}$ which are morphologically very similar to $\mathrm{MSCH}$. Unlike $\mathrm{MSCH}$, they have colonic epithelium with serrated architecture and express perineural markers such as EMA, whereas they are negative for $\mathrm{S}-100$ protein. $^{2}$

Finally, inflammatory fibroid polyps (Vanek's tumor) can be confused with MSCH. They are composed of stellate or spindleshaped, bland stromal cells that are arranged in an onion skinlike pattern around blood vessels and mucosal glands. They have inflammatory infiltrates dominated by eosinophils, which are not observed in $\mathrm{MSCH}$. Additionally, they are not immunoreactive for S-100 and are extremely rare in the colon.

$\mathrm{MSCH}$ is a rare benign lesion, and cases with clinical features are summarized in Table 1. Cases are primarily detected as small polyps that range from 1 to $8 \mathrm{~mm}$ (mean, $5 \mathrm{~mm}$ ) and are predominantly located in the rectosigmoid colon. Patients are typically asymptomatic, and none of the patient cases were associated with an inherited syndrome. The clinical features of this case are similar to those summarized in Table 1.

In summary, $\mathrm{MSCH}$ is a rare lesion that can be found incidentally during routine colonoscopy. Although there is currently no indication that $\mathrm{MSCH}$ is related to inherited syndromes or malignancies, it is important for pathologists to include it in the differential diagnosis of S-100-positive spindle cell proliferative lesions for accurate diagnosis and to prevent aggressive or unnecessary treatments.

\section{Conflicts of Interest}

No potential conflict of interest relevant to this article was reported.

\section{REFERENCES}

1. Gibson JA, Hornick JL. Mucosal Schwann cell "hamartoma": clinicopathologic study of 26 neural colorectal polyps distinct from neurofibromas and mucosal neuromas. Am J Surg Pathol 2009; 33: 781-7.

2. Klair JS, Girotra M, Agarwal A, Aduli F. Mucosal Schwann cell hamartoma: just benign or more? Int J Colorectal Dis 2014; 29: 1597-8.

3. Bae MN, Lee JE, Bae SM, et al. Mucosal Schwann-cell hamartoma diagnosed by using an endoscopic snare polypectomy. Ann Coloproctol 2013; 29: 130-4.

4. Neis B, Hart P, Chandran V, Kane S. Mucosal schwann cell hamartoma of the colon in a patient with ulcerative colitis. Gastroenterol Hepatol (NY) 2013; 9: 183-5.

5. Rocco EG, Iannuzzi F, Dell'Era A, et al. Schwann cell hamartoma: case report. BMC Gastroenterol 2011; 11: 68.

6. Pasquini P, Baiocchini A, Falasca L, et al. Mucosal Schwann cell "Hamartoma": a new entity? World J Gastroenterol 2009; 15: 2287-9.

7. Sagami S, Fukumoto A, Amano M, et al. A case of mucosal Schwann cell hamartoma. Nihon Shokakibyo Gakkai Zasshi 2012; 109: 1776-83.

8. Ferro de Beça F, Lopes J, Maçoas F, Carneiro F, Lopes JM. Tactoid body features in a Schwann cell hamartoma of colonic mucosa. Int J Surg Pathol 2014; 22: 438-41.

9. Kanar O, Nakshabendi R, Berry AC. Colonic mucosal Schwann cell hamartoma on incidental screening colonoscopy. J Gastrointestin Liver Dis 2015; 24: 411.

10. Bae JM, Lee JY, Cho J, Lim SA, Kang GH. Synchronous mucosal Schwann-cell hamartomas in a young adult suggestive of mucosal Schwann-cell harmatomatosis: a case report. BMC Gastroenterol 2015; 15: 128. 